\title{
Assessment of the Opinion of Youths on the Use of Sports and Vocational Education for Crisis Management in the Niger Delta Region
}

\author{
Thomas Boye Ejobowha ${ }^{1}$, Johnson Ighowho Erhinyodavwe ${ }^{2}$, Valentine Othuke Oroka ${ }^{3} \&$ Rachael Atomatofa $^{4}$ \\ ${ }^{1}$ Department of Sports and Health Education, Delta State College of Physical Education, Mosogar, Nigeria \\ ${ }^{2}$ Department of Educational Foundations, Delta State College of Physical Education, Mosogar, Nigeria \\ ${ }^{3}$ Department of Business Education, Delta State College of Physical Education, Mosogar, Nigeria \\ ${ }^{4}$ Department of Integrated Science, Delta State College of Physical Education, Mosogar, Nigeria
}

Correspondence: Thomas Ejobowha Boye, Department of Sports and Health Education, Delta State College of Physical Education, Mosogar, Nigeria. Tel: 234-803-394-4707. E-mail: dr.thomasboye@yahoo.co.uk

Received: October 13, 2013

Accepted: February 7, $2014 \quad$ Online Published: February 22, 2014

doi:10.5539/ijps.v6n1p87

URL: http://dx.doi.org/10.5539/ijps.v6n1p87

\begin{abstract}
The study was carried out to assess the opinion of youths in the Niger Delta Region of Nigeria on the use of sports and vocational education in crisis management. To effectively carry out the study, five null hypotheses were formulated to guide the study. The survey research design was used for the study. The sample for the study comprises of one thousand youths purposively sampled from the nine oil producing states commonly referred to as the Niger Delta region. A self generated questionnaire tailored towards a four point Likert type was used for gathering information. The reliability of the instrument was ascertained by a test-retest method using the Pearson Product Moment Correlation Coefficient and the reliability of 0.87 was ascertained. Percentages and mean were used in analysing the demographic data while Chi-square was used in testing the hypothesis at 0.05 level of significance. The result of the findings revealed that there is a significant relationship between sporting activities and crisis management. The study also revealed that there is a significant relationship between vocational skill acquisition through vocational education and crisis management. Age, level of education and parental background significantly influence the opinion of youths on the use of sports and vocational education for crisis management. It was recommended that government and well meaning Nigeria should help to provide facilities and vocational skill acquisition centres in the Region.
\end{abstract}

Keywords: youths, crisis management, sports, vocational education, Niger Delta

\section{Introduction}

\subsection{Background to the Study}

The Niger Delta region of Nigeria which comprises of Delta, Edo, Rivers, Bayelsa, Cross Rivers, Ondo, Akwa-Ibom, Abia and Imo states are known for its natural deposit of mineral resources especially crude oil. The region has a coastline of $560 \mathrm{~km}$, which occupies two-thirds of Nigeria's coastline. It has a geographical size of $70,000 \mathrm{sq} \mathrm{km}$ ( 7.5 percent of Nigeria's total) and a population of 30 million people located in 3,000 communities and spread over 40 ethnic groups who speak 250 different dialects. It boasts of nineteen billion barrels of oil reserves and 166 trillion cubic feet of natural gas (Akpabio, 2009). In the past three to four decade, the region has been on the forefront in the economic sustenance through the derivation from crude oil. It is on record that the main source of revenue to the nation is in the production and export of the crude oil being extracted from the region.

The Niger Delta region has drawn the attention of the entire world in recent time due to what was termed "Niger Delta crisis". The crisis degenerated to hostage taking of foreigners and non foreigners alike. The crises came to its climax in the late 90s to the mid 20s precisely between 1999- 2008 when even classroom teachers were taken as hostages for ransom. These were checkmated with the introduction of the amnesty programme by the late President Yar'Adua in 2009 were majority of the youths in the Niger Delta region embraced and accepted the amnesty offer. Massive weapons of destructions were surrendered and handed to the Federal Government of 
Nigeria. The government came up with the amnesty programme but was faced with a lot of challenges. Although the programme is at the post amnesty stage, that is, the stage of rehabilitation and integration, a lot needed to be done.

The stage, at which the programme is presently, needs experts in crisis management, sociologist, psychologist, and professionals in conflict resolution to intervene. Others that must not be neglected are educationists, practical skill acquisition experts, and Information Communication Technology (ICT) experts. Despite the fact that the amnesty programme is at the rehabilitation and integration stage, majority of the youths and adults in the region have resorted to hostage taking for ransom in recent times This ugly trend calls for scholarly researches for a more sustainable programme that will help integrate, rehabilitate and redirect the attention of those who are more likely to be involved in this criminal acts of hostage taking, pipeline vandal, and other forms of crisis in other to make them useful and be productive to the region and the nation at large.

It is based on this premise that the researchers wish to carry out a study on managing crisis in the Niger Delta region with the use of Sports, and Vocational Education for sustainable development in Nigeria.

According to Whawo (2011) crisis of various magnitudes often arises when people within a geographical location misunderstand themselves for whatever reasons. Also conflict or crisis may erupt when the interest of people become incompatible and translated into attitudes unusual hostilities that breathes out violence. Whawo (2011) mention various ways by which crisis or conflict could be managed, among them are; negotiation, mediation and diplomacy, arbitration and litigation.

A study carried out by the Australian Institute of Criminology has identified that the use of sports for youth crime prevention and crisis management has shown that sports and physical activity can combine with other interventions to reduce crime and antisocial behaviours in particular groups and community. Cameron and MacDougall (2006) asserted that the role of sports in diverting young people from criminal activities and crisis or rehabilitating them and reducing the amount of crime in local areas has been stressed by researchers and a study found that sports was most effective when combined with programmes addressing wider social development. Boye (2004) reported that sports create an avenue for peaceful coexistence. As above could sports be a panacea for peaceful coexistent in the midst of the present situation in the Niger Delta region?

Keim (2003) stated that sport is not only a physical activity, but also an area where people interact socially. Sport participation can enhance self-concept, self-esteem, and self-confidence and sports is believed to have the potentials to foster individual empathy, tolerance, cooperation, social skill and team work (Amara, 2006).

For sports a number of international frameworks report on the relationship between sports and peace. The UN Inter Agency Task Force on Sports Development and Peace (2003) identified that well designed sports based initiatives that incorporate the best value of sports can be powerful, practical and cost effective tools to achieve development and peace objectives.

There is that belief that a strong scientific legacy in science needs effective democracy to thrive. The Obasanjo scientific legacy reflects his conviction that if Nigeria is to become a leading player in the global economy by 2020 , it must invest in and subsequently harness the potential of science and technology. Science and technology should be kept at a high political priority. Since only half the population has access to clean water, science and technology are applied to alleviate these needs. Accordingly, science can solve the problem of poverty and hunger in the Niger-Delta region (Obiagelli, 2007). This is a compliment of the tendency of vocational education in arresting or managing crisis in the Niger Delta Region.

It may be evidenced that the role sports, and vocational education is likely to play in the managing of the crisis in the Niger Delta region cannot be overemphasized. Most of the militants involved in this social vices leading to crisis in the Niger-Delta region are youths who may not be able to provide for themselves, and who may lack skills to create employment for livelihood as a result of ignorance which might be the product of lack of education.

Education according to Ibikunle (2003) is an investment in human capital with the sole aim of wiping out ills such as ignorance, disease, unemployment, superstitious beliefs, nepotism and economic stagnation that usually plague an illiterate society. Simply put, education is the resolution to all psycho-social, political and economic problems. Education is the overall development of an individual-physically, intellectually, morally, emotionally, and socially (Nsude, 1998). In reflection of these facts, adult and non-formal education stands the course to eradicate illiteracy, ignorance and all the social ills mentioned above. This makes vocational education which is a branch of general education, a skill venture education, a sustainable vital tool for managing crisis in the Niger Delta region. 
A superficial view of vocational education leads one to assume that its major role lies in the preparation of youngsters for their first entry into the world of work. This is certainly one of its major functions, but an equally great responsibility is the education in vocational areas of persons who are out of school. Such education falls within the fabric of continuing, adult and non-formal education. Vocational education involves acquisition of skills, abilities, attitudes, competencies, work habits and knowledge geared towards practical work and self-reliance.

According to Oroka (2007), Vocational Education is concerned with the preparation of individuals for skill performance. The major occupational areas in vocational education are; Vocational Agriculture, Distributive Education, Home Economics Education, Health Occupation, Trade and Commercial Education, Business and Office Education. In most cases, Vocational Education is usually merged with Vocational and Technical Education (VTE). Vocational and Technical Education (VTE) is a highly useful education because its occupational content offers the trainees the opportunity to acquire skills, attitudes, interest and knowledge to perform socially and economically, such work that is beneficial not only to themselves but to the society in general. Vocational and Technical Education in (VTE) the general sense is that kind of training pertaining to or characterized of a particular arts, science, profession or occupation. VTE is that aspect of the education process involving, in addition to General Education, the study of technologies and related science and the acquisition of practical skills, attitude, understanding and knowledge related to occupation in various sectors of life (Oroka, 2007). This shows that Vocational Technical Education is all embracing and touches every aspect of human development and activity. The Federal Republic of Nigeria (FRN, 2004) defined Vocational Technical Education as that aspect of education, which leads to the acquisition of practical and applied skills and basic scientific skills and knowledge. It is a group of learning experience, which is meant to be systematically imparted to an individual in order to get him adequately equipped with skills for a gainful employment in a recognized occupation. Essentially Vocational and Technical Education is a problem solving process with the main objectives of improving the quality of human life. It draws from various branches of knowledge to solve practical tasks. From the above premise the proper application of Vocational/Technical Education may go a long way in rebranding the youths in the Niger Delta region with the view of preventing, and managing crisis in the region.

Any programme that is capable of bringing peace and sustainable development in the Niger Delta region should be conceived to be a welcome project that needs critical thinking and adequate backing. Based on this premises can Sports and Vocational Education therefore be utilized for crisis management in the Niger Delta region of Nigeria?

\subsection{Statement of the Problem}

The Niger Delta region of Nigeria which accounted for well over $80 \%$ of the total revenue has been witnessing a lot of crisis which got to its peak in 2008 that led to the Federal Government through security meetings with stakeholders decided to find solution to the lingering crisis by granting amnesty to the militants in the region. The amnesty programme has been on since the expiration of the deadline given to the militants to surrender their weapons of massive destructions by the Federal Government. The government, multinational companies, private individual and the general public have been finding solution in different ways to prevent, manage or minimize the lingering crisis. It is based on this premise that these researchers carried out this study to ascertain if sports and vocational education could be used for crisis management in the Niger Delta region of Nigeria for sustainable development.

\subsection{Purpose of the Study}

The purpose of this study is to find out if Sports and Vocational Education through skill acquisition can help in managing the crisis in the Niger Delta region. As scholars who wish to contribute to societal growth, it is obvious that in the midst of continuous and prevailing crisis no meaningful development can be achieved. Hence the need arose to carry out a study on how to prevent the occurrence of violent crisis and to manage crisis when they occur so as to attract meaningful and sustainable development in the region.

\subsection{Significance of the Study}

The findings from the study when properly implemented will be of immense benefits to the youths, parents, government, multinational oil companies, and people of the Niger Delta region and Nigeria in general. It is an established fact that idleness as a result of joblessness is one of the reasons for the much antisocial behaviour that results to violence in our society. With proper application of sporting activities, science based skill acquisition technology through ICT, introduction of Vocational skill acquisition programmes and adult/non-formal education in the Niger Delta region with special emphasis on those in riverine and rural areas were the bulk of 
the nations mineral resources are been drilled, sustainable development and peaceful coexistence will be attained. Through sporting activities, and provision of sports facilities, science based skill acquisition, vocational skill acquisition a lot of jobs could be created. Self reliance due to practical skill acquisition will be a significant benefit of this study. If idleness is eradicated peace could be guaranteed to a large extent. Scholars who wish to embark on studies relating to conflicts and crisis prevention/management may find this material to be a vital tool readily available as resource material. Finally the work will be useful in the amnesty programme for the repentant militant in the Niger-Delta region and Nigeria in general.

\section{Hypotheses}

The following hypotheses are generated to guide the study:

1) There will be no significant relationship between sporting activities and the managing of crisis in the Niger Delta region.

2) There will be no significant relationship between vocational skill acquisition through vocational education, and the managing of crisis in the Niger Delta region.

3) Age will not significantly influence the opinion of youths on the use of sports and vocational education in crisis management in the Niger Delta region of Nigeria.

4) level of education will not significantly influence the opinion of youths on the use of sports and vocational education in crisis management in the Niger Delta region of Nigeria.

5) Parent background will not significantly influence the opinion of youths on the use of sports and vocational education in crisis management in the Niger Delta region of Nigeria.

\section{Method/Procedure}

\subsection{Design}

A descriptive survey research design was adopted for the study.

\subsection{Population}

The Population for the study included all youths within the ages of 18-52 with a mean age of 35 in the nine states of the Niger Delta Region.

\subsection{Sample and Sampling Procedure}

The sample for the study comprised 1000 randomly selected youth from five states of the nine states of the Niger Delta Region. The stratified sampling techniques method was adopted in selecting the respondents.

\subsubsection{Research Instrument}

The instrument used for the study was a self developed questionnaire tagged Crisis Management Questionnaire through Sports, and Vocational Education (CMQTSVE). The instrument consists of responses based on strongly agreed (SD), agreed (A) strongly disagreed (SD) and disagreed (D). A jury of 10 experts drawn from the Faculty of Education validated the instrument, while the reliability was established by a test-retest method using the Pearson Product Moment Correlation Coefficient and the reliability of 0.87 was ascertained.

\subsubsection{Administration of Instrument}

The instrument for the study was administered to the respondents with the services of 18 (eighteen) trained research assistance who are conversant with the communities in the Niger Delta region and to also checkmate Language barrier. The administration and collection of the instrument was done in eight weeks. A total of 820 questionnaire was dully filled and returned. The return rate was $82 \%$.

\subsection{Method of Data Analysis}

The descriptive statistics of Percentage and Mean were used in analysing the demographic data while the Chi-square was used to test the hypotheses at 0.05 level of significant. 


\section{Result of Study}

Table 1. Percentage of respondents by gender

\begin{tabular}{ccc}
\hline Gender & Respondents & Percentage \\
\hline Male & 480 & 58.5 \\
Female & 340 & 41.5 \\
Total & 820 & 100.0 \\
\hline
\end{tabular}

Table 1 shows that $58.5 \%$ of the respondents used for the study are male while $41.5 \%$ are female. The table shows that gender sensitivity was taken into consideration.

Table 2. Percentage analysis by age of respondents

\begin{tabular}{cccc}
\hline Age & Mean Age & F & Percentage \\
\hline $18-24$ & 21 & 208 & 25.4 \\
$25-31$ & 28 & 217 & 26.5 \\
$32-38$ & 35 & 189 & 23.0 \\
$39-45$ & 42 & 105 & 12.8 \\
$46-52$ & 49 & 101 & 12.3 \\
Total & 35 & 820 & 100.0 \\
\hline
\end{tabular}

Table 2 represents the various age groups with their mean age and percentages used for the study. The average mean age of the respondents is 35 . However age 28 and 21 have the highest frequencies used for the study.

Table 3. Percentage analysis of respondents occupation

\begin{tabular}{ccc}
\hline Occupation & Frequencies & Percentage \\
\hline Applicants & 229 & 27.9 \\
Traders & 88 & 10.7 \\
Carpenters & 45 & 5.5 \\
Civil Servant & 73 & 8.9 \\
Politicians & 103 & 12.6 \\
Transporter & 120 & 14.6 \\
Fishing/ farming & 162 & 19.8 \\
Total & 820 & 100.0 \\
\hline
\end{tabular}

Table 3 represents the occupation of respondents used for the study. The table indicates that applicants have the highest with $27.9 \%$ with a frequency of 229 , followed by fishing/farming with $19.8 \%$ and a frequency of 162 . 
Table 4. Percentage analysis of parent's profession

\begin{tabular}{ccc}
\hline Parents Profession & Frequencies & Percentage \\
\hline Fishing & 135 & 16.5 \\
Trading & 187 & 22.8 \\
Farming & 148 & 18.0 \\
Teacher & 48 & 5.9 \\
Business & 102 & 12.4 \\
Transporter & 113 & 13.8 \\
Politician & 87 & 10.6 \\
Total & 820 & 100.0 \\
\hline
\end{tabular}

Table 4 represents the percentages of parents and their frequencies use for the study. The table indicates that trading and farming have the highest with $22.8 \%$ and $18.0 \%$ respectively.

Table 5. Percentage analysis of respondents level of education

\begin{tabular}{ccc}
\hline Educational Qualification & Frequencies & Percentage \\
\hline No formal Education & 52 & 6.3 \\
First school leaving certificate & 124 & 15.1 \\
Secondary school leaving certificate & 245 & 29.9 \\
Diploma & 154 & 18.9 \\
NCE & 103 & 12.6 \\
University Graduate & 102 & 12.4 \\
Msc & 25 & 3.0 \\
PhD & 15 & 1.8 \\
Total & 820 & 100.0 \\
\hline
\end{tabular}

Table 5 represents the level of education of respondents used for the study. The table indicates that $29.9 \%$ of the respondents are secondary school certificate holders while those with no formal education are $6.3 \%$. The overall table indicates that over $75 \%$ of the respondents have formal education.

Hypothesis 1: There will be no significant relationship between sporting activities and the managing of crisis in the Niger Delta region.

Table 6. Chi-square analysis on the relationship between the opinions of youths on the use of sports in crisis management in the Niger Delta Region

\begin{tabular}{ccccccc}
\hline Responses & Frequencies & Percentage & Df & $\begin{array}{c}\text { Critical } \\
\text { value }\end{array}$ & $\begin{array}{c}\text { Calculated } \\
\text { value }\end{array}$ & Decision \\
\hline SA & 407 & 49.6 & & & & \\
A & 308 & 37.6 & & & & \\
D & 102 & 12.4 & 3 & 7.82 & $43.08^{*}$ & Rejected \\
SD & 3 & 0.4 & & & & \\
Total & 820 & 100.0 & & & & \\
\hline
\end{tabular}

*Significant at 0.05 alpha level. 
Table 6 above shows that 407 of the respondents representing $49.6 \%$ strongly agreed, while 308 respondents representing $37.6 \%$ agreed, on the contrary 102 representing $12.4 \%$ and 3 representing $0.4 \%$ disagreed and strongly disagreed respectively. The obtained $\mathrm{x}^{2}$ value of 43.08 is greater than the table critical value of 7.82 meaning that the stated hypothesis 1 above is rejected.

Hypothesis 2: There will be no significant relationship between vocational skill acquisition through vocational education, and the managing of crisis in the Niger Delta region.

Table 7. Chi-square analysis on the relationship between the opinions of youths on the use of vocational skill acquisition through vocational education in crisis management in the Niger Delta Region

\begin{tabular}{ccccccc}
\hline Responses & Frequencies & Percentage & Df & $\begin{array}{c}\text { Critical } \\
\text { value }\end{array}$ & $\begin{array}{c}\text { Calculated } \\
\text { value }\end{array}$ & Decision \\
\hline SA & 363 & 44.3 & & & & \\
A & 315 & 38.4 & & & & \\
D & 83 & 10.1 & 3 & 7.82 & $28.08^{*}$ & Reject \\
SD & 59 & 7.2 & & & \\
Total & 820 & 100.0 & & & \\
\hline
\end{tabular}

*Significant at 0.05 alpha level.

Table 7 above shows that 363 of the respondents representing $44.3 \%$ strongly agreed, while 315 respondents representing $38.4 \%$ agreed, on the other hand 83 representing $10.1 \%$ and 59 representing $7.2 \%$ disagreed and strongly disagreed respectively. Table 7 shows that the critical or table value of $X^{2}$ at 0.05 alpha level is 7.82 while the calculated value is 28.08 . Since the calculated value is greater than the critical value the null hypothesis was therefore rejected. This means that there is a significant relationship between vocational skill acquisition through vocational education and crisis management.

Hypothesis 3: Age will not significantly influence the opinion of youths on the use of sports and vocational education in crisis management in the Niger Delta region of Nigeria.

Table 8. Chi-square analysis of respondents age as it influences their opinion on the use of sports and vocational education in crisis management in the Niger Delta Region

\begin{tabular}{ccccccc}
\hline Responses & Frequencies & Percentage & Df & $\begin{array}{c}\text { Critical } \\
\text { value }\end{array}$ & $\begin{array}{c}\text { Calculated } \\
\text { value }\end{array}$ & Decision \\
\hline SA & 373 & 46.7 & 3 & 7.82 & $48.38^{*}$ & Reject \\
A & 395 & 48.2 & & & & \\
D & 33 & 4.0 & & & & \\
SD & 19 & 1.1 & & & & \\
Total & 820 & 100.0 & & & & \\
\hline
\end{tabular}

*Significant at 0.05 alpha level.

Table 8 shows that $X^{2}$ critical value is 7.82 while the calculated value is 48.38 at 0.05 alpha level at 3 degree of freedom. In as much as the calculated value is greater than the critical value the null hypothesis was rejected at $X^{2}=48.38 ; \mathrm{df}=3, P<0.05$. This means that age significantly influences the opinion of youths on the use of sports and vocational education in crisis management in the Niger Delta Region.

Hypothesis 4: Level of education will not significantly influence the opinion of youths on the use of sports and vocational education in crisis management in the Niger Delta region of Nigeria. 
Table 9. Chi-square analysis of level of education as it influences the opinion of youths on the use of sports and vocational education in crisis management in the Niger Delta Region

\begin{tabular}{ccccccc}
\hline Responses & Frequencies & Percentage & Df & $\begin{array}{c}\text { Critical } \\
\text { value }\end{array}$ & $\begin{array}{c}\text { Calculated } \\
\text { value }\end{array}$ & Decision \\
\hline SA & 383 & 46.7 & 3 & 7.82 & $53.38^{*}$ & Reject \\
A & 395 & 48.2 & & & & \\
D & 33 & 4.0 & & & \\
SD & 9 & 1.1 & & & \\
Total & 820 & 100.0 & & & & \\
\hline
\end{tabular}

*Significant at 0.05 alpha level.

Table 9 indicates that $X^{2}$ critical value is 7.82 while the calculated value is 53.38 at 0.05 alpha level at 3 degree of freedom. Since the calculated value is greater than the critical value the null hypothesis was rejected at $\mathrm{X}^{2}=$ 53.38; $\mathrm{df}=3, \mathrm{P}<0.05$. This means that level of education significantly influences the opinion of youths on the use of sports and vocational education in crisis management in the Niger Delta Region.

Hypothesis 5: Parent background will not significantly influence the opinion of youths on the use of sports and vocational education in crisis management in the Niger Delta region of Nigeria.

Table 10. Chi-square analysis of the opinion of youths on parent background as it influences the use of sports and vocational education in crisis management in the Niger Delta Region

\begin{tabular}{ccccccc}
\hline Responses & Frequencies & Percentage & Df & $\begin{array}{c}\text { Critical } \\
\text { value }\end{array}$ & $\begin{array}{c}\text { Calculated } \\
\text { value }\end{array}$ & Decision \\
\hline SA & 289 & 35.2 & 3 & 7.82 & $48.26^{*}$ & Reject \\
A & 449 & 54.8 & & & & \\
D & 33 & 4.0 & & & & \\
SD & 49 & 6.0 & & & & \\
Total & 820 & 100.0 & & & & \\
\hline
\end{tabular}

*Significant at 0.05 alpha level.

Table 10 indicates that $X^{2}$ critical value is 7.82 while the calculated value is 48.26 at 0.05 alpha level at 3 degree of freedom. Since the calculated value is greater than the critical value the null hypothesis was rejected at $\mathrm{X}^{2}=$ 48.26; $\mathrm{df}=3, \mathrm{P}<0.05$. This means that parent's background significantly influences the opinion of youths on the use of sports and vocational education in crisis management in the Niger Delta Region.

\section{Discussion}

The general findings of the study revealed that youths of the Niger Delta Region of Nigeria are of the opinion that sports and vocational skill acquisition through vocation education can help in managing crisis in the region. The finding of the study is in consonant with Keim (2003), Boye (2004), Cameron and MacDougall (2006) who in different studies came up with the assertion that sports facilitate unity and help in making individual stay out of trouble. Similarly, Oroka (2007) in a study came up with the findings that vocational skill acquisition through vocational education is a sure road map to youth empowerment in the Niger Delta Region. The present study confirms the assertion of Oroka (2007) that with well package skill acquisition programmes youth restiveness will be seriously checkmated.

The study also affirms earlier research studies (Eboh \& Boye, 2005; Eboh, Money, \& Boye, 2007; Whawo, 2011), that age, level of education and parental background affects opinion of individuals when taken sensitive decisions on issues confronting them. According to Ogalanya (1996) those without vocational skills will find it difficult to gain meaningful employment in this dispensation where emphasis is gradually tilting toward vocational skill acquisition. Akpotowho and Amahi (2006), Salome, Osita and Marcel (2012) noted that graduates who do not concentrate on skill acquisition will find it very difficult to gain better pay employment. 
Similarly, youths who want to meet up with their contemporary in this ever changing world without meaningful vocational skill will end up depending on those with practical skill jobs.

\section{Conclusion and Recommendations}

The result of this study has affirmed that sports and vocational skill acquisition through vocational education can be used for crisis management. In view of this the researchers came up with the following suggestions.

1) Sports facilities and equipment should be made available to communities in the Niger Delta Regions and to those that already have some facilities, those facilities should be upgraded to meet the required standards.

2) Sports coaches should be made available to these communities to teach and coach athletes in the various sporting activities.

3) Sports tournaments should be periodically organized to constantly involve the youths so as to keep them from being idle. Prizes and award ranging from cash award to scholarships should be given to deserving athletes who perform well to encourage them.

4) Vocational skill acquisition centers should be established in all communities in the Niger Delta Region.

5) Trained and professional instructors should be made available in all the established vocational skill centers.

6) Government and meaningful Nigerians including Multi-National oil companies should empower youths with the necessary take off money and equipment after skill acquisition.

7) Adequate monitoring and periodic empowerment of youths who have undergone skill acquisition training should not be neglected.

\section{Acknowledgements}

We wish to sincerely appreciate and thank Tertiary Educational Trust Fund (TETFUND) who sponsored this research study. Special thanks to the Management of the Delta State College of Physical Education Mosogar, who made the funds available as at when due, without which this very robust and demanding research wouldn't have been possible.

\section{References}

Akpabio, G. (2009). The Niger-Delta crises and the challenges of leadership. The Godswill Akpabio's Model. A paper delivered by his Excellency Chief Godswill Obot Akpabio, Executive Governor of Akwa-Ibom State at the National Round-table in Abuja on Monday May $25^{\text {th }}, 2009$.

Akpotowho, F. C., \& Amahi, F. U. (2006). Perceptions of business teacher's educators and small business operators on identified critical factors for a successful entrepreneurship. Business Education Journal, 5(2), 72-81.

Amara, M. (2002). Roles of Sport in International Platform on Sport and Development. Retrieved May 29, 2009, from http://www.sportanddev.org/en/projects/sce-all-projects/brezovica-summer-camp-2002-for-lipjanlipjan-you th.htm

Boye, T. E. (2004). Sports as a medium for facilitating unity among ethnic group in Delta State. (Unpublished Masters Dissertation Delta State University, Abraka).

Cameron, M., \& MacDougall, C. (2006). Crime Prevention through Sport and Physical Activity. In Australian Institute of Criminology (2000), Trends and Issues in Crime and Criminal Justice. No. 165, 2000.

Eboh, L. O., \& Boye, T. E. (2005). Physical activity behaviours of Female Pupils and possible Influences of Urban Environment on Eating. Pakistan Journal of Nutrition, 4(6), 361-365.

Eboh, L. O., Money F. O., \& Boye, T. E. (2007). Implication of Recreation Participation Profile and Perceived wellness among academic Staff in Delta Tertiary Institution of Higher Learning. Journal of Nigerian Association of sports science and Medicine, ix, 105-109. http://dx.doi.org/10.3923/pjn.2005.361.365

Keim, M. (2003). Sport as Opportunity for Community Development and Peace Building in South Africa. In Y. V. Auweele, C. Malcom, \& B. Meulders (Eds), Sport and Development. Leuven, Belgium: Lannoo Campus.

Federal Republic of Nigeria. (2004). National Policy on Education (4th ed.). Lagos: NERDC Press.

Ibinkule, W. (2003). Teachers qualification and Academic Achievement of secondary school students in integrated science. Journal of educational development, 4, 37-40. 
Musa, S. M. (2009). How UBE can succeed. The Guardian, 27.

Naude, I. (1998). Principles and practice of education. Benin City: A Lowis publishers.

Obiagelli, E. (2007). Education in Nigeria. Retrieved from http://www.globalenvision.org/library/2316127

Ogalanya, G. A. O. (1996). Enhancing skill development through school-industry linkage in vocational technical education. Research and publication Unit, Federal College of Education (T).

Oroka, O. V. (2007). Vocational Technical Education: A vehicle for conveying skills required for youth's empowerment in Nigerian Economy. Journal of Business and Management Studies, 1(2), 166-171.

Salome, E. N., Osita, I., \& Marcel, E. C. (2012). Entrepreneurship skills required by business related graduates for successful operation of a business enterprise in Enugu commercial centre and Environs. Kuwait Chapter of Arabian Journal of Business and Management Review, 2(8), 1-14002E.

UNESCO. (1997). Educating for sustainable future: A transdisciplinary vision for concerted action. UNESCO. Retrieved January 13, 2010, from http//unesco.org/images

UNDP. (2005). Human Development Report on Nigeria. A publication of the United Nations Development Project.

United Nations. (2003). UN Inter Agency Task Force Report on Sport for Development and Peace: Towards Achieving the Millennium Development Goals. Geneva.

Whawo, D. D. (2011). Conflict Resolution and its Implication for Teachers. In A. I. Joe, \& D. D. Whawho (Eds.), Emergent Problems in Nigerian Education (pp. 197-211). Ibadan: Kraft Books Limited.

\section{Copyrights}

Copyright for this article is retained by the author(s), with first publication rights granted to the journal.

This is an open-access article distributed under the terms and conditions of the Creative Commons Attribution license (http://creativecommons.org/licenses/by/3.0/). 